\title{
Dampak Teknologi Informasi terhadap Kondisi Ekonomi Mahasiswa di Masa Pandemi Covid
}

\author{
M Sya'rani Machrizzandi \\ Jurusan Teknik Informatika, Universitas Islam Negeri Alauddin Makassar \\ Sya'rani.machrizzandi@uin-alauddin.ac.id
}

\begin{abstract}
Abstrak
Teknologi informasi menjadi kebutuhan primer saat ini dimana seluruh dunia termasuk Indonesia dilanda wabah corona virus yang mematikan dan mengakibatkan seluruh sektor bergantung pada teknologi. Penggunaan teknologi informasi ini bertujuan untuk meminimalisir dan mereduksi potensi penyebaran virus mematikan tersebut, tidak terkecuali di sektor Pendidikan. Di masa pandemi ini, mahasiswa mengikuti perkuliahan jarak jauh dengan menggunakan teknologi informasi. Tantangan terbesar terlihat pada sektor ekonomi, dimana mahasiswa harus memiliki kuota dan koneksi internet yang mumpuni dalam mengikuti proses perkuliahan. Sehingga penelitian ini akan mengkaji dampak teknologi informasi terhadap kondisi ekonomi mahasiswa di masa pandemi covid. Penelitian ini dianalisis menggunakan statistik deskriptif untuk menunjukkan pengaruh teknologi informasi terhadap kondisi ekonomi mahasiswa. Dari hasil analisis tersebut diketahui bahwa dampak teknologi informasi sangat besar terhadap kondisi perekonomian mahasiswa bahkan juga dirasakan oleh orang tua mahasiswa. Sehingga tidak sedikit dari mahasiswa memilih untuk mundur dari proses perkuliahan pada semester berjalan karena keterbatasan ekonomi dalam memenuhi kebutuhan teknologi informasi Pendidikan (perkuliahan daring).
\end{abstract}

Kata Kunci: teknologi informasi, pandemi covid-19, kuliah daring, ekonomi, keterbatasan, kuota internet

\section{PENDAHULUAN}

Sejak akhir tahun 2019 dilaporkan bahwa virus corona jenis baru atau SARS-CoV-2 pertama kali muncul. Virus yang menyebabkan gangguan pernafasan itu telah menyebar ke hampir semua negara di dunia. Penyebarannya begitu cepat, tiga bulan setelah laporan pertama di Wuhan China, virus itu telah masuk ke Indonesia. Melihat sebaran virus corona, organisasi kesehatan dunia WHO telah mendeklarasikan bahwa Covid-19 sebagai pandemi global. Sebagai upaya penghentian laju penyebaran virus, banyak negara yang menerapkan lockdown untuk menghentikan segala aktivitas keluar maupun yang akan masuk kedalam negeri. Di Indonesia sendiri, meskipun tidak sepenuhnya menerapkan lockdown, 
namun banyak daerah yang menerapkan Pembatasan Sosial Berskala Besar (PSBB) di wilayahnya masing-masing. Masyarakat diminta untuk berdiam diri di rumah dan mengurangi kegiatan diluar rumah.

Membatasi diri untuk tetap tinggal di rumah dalam jangka waktu lama tentu menimbulkan banyak sekali akibat. Tujuan utama untuk memutus mata rantai penyebaran virus corona memang tepat sasaran. Namun hal ini juga menimbulkan berbagai dampak negatif, terutama pada sektor perekonomian dan pendidikan di Indonesia. Banyak sekali kerugian yang dialami oleh industri besar, menengah maupun kecil yang berujung pada pemutusan hubungan kerja (PHK) bagi para karyawannya. Pada sektor pendidikan, kegiatan belajar-mengajar terpaksa harus dilakukan dengan menggunakan sistem daring. Meskipun belum belum penelitian resmi yang menyatakan seberapa besar efektivitas pembelajaran sistem daring ini dibandingkan dengan pembelajaran secara manual, namun melihat realitas saat ini banyak dari kaum pelajar dan mahasiswa yang mengeluhkan pembelajaran jarak jauh tersebut. Fenomena ini semakin lama menimbulkan berbagai dampak, terutama pada aspek perekonomian mahasiswa.

Pembelajaran Jarak Jauh dirancang agar mahasiswa bisa belajar secara virtual dengan memanfaatkan teknologi informasi. Biasanya mahasiswa bertemu dengan dosen pada jam pembelajaran yang telah ditetapkan oleh pihak institusi. Selain itu, mahasiswa juga diberikan tugas secara mandiri yang harus dikumpulkan kepada dosen. Tidak hanya proses pembelajaran yang dilakukan secara virtual, proses ujian pun dilakukan secara virtual. Sebagian besar menggunakan aplikasi pertemuan virtual seperti Zoom dan Google Meet saat proses pembelajaran. Oleh karena itu, mahasiswa dan dosen sangat memerlukan peralatan IT seperti laptop dan smartphone dalam proses pembelajaran. Tak lupa, kuota atau wifi juga diperlukan agar proses pembelajaran secara virtual bisa berjalan dengan baik.

Meskipun Pembelajaran Jarak Jauh (PJJ) dilaksanakan untuk mencegah penyebaran COVID-19, namun bukan berarti pembelajaran ini bebas hambatan. Banyak pihak mengatakan bahwa pandemi virus Corona membuat hambatan belajar. Hal ini karena semua tidak bisa belajar secara tatap muka di kelas, tapi harus belajar di rumah dengan menggunakan teknologi informasi. Padahal tidak semua mahasiswa memiliki kemampuan yang memadai untuk melaksanakan Pembelajaran Jarak Jauh (PJJ). Terutama persoalan kemampuan finansial, sehingga penelitian ini bertujuan untuk mengidentifikasi dampak teknologi informasi terhadap kondisi ekonomi mahasiswa di masa pandemi covid.

\section{TINJAUAN PUSTAKA}

\section{A. Pengertian Teknologi Informasi}

Menurut William \& Sawyer dalam Abdul Kadir \& Terra CH (2003), teknologi informasi didefinisikan sebagai teknologi yang menggabungkan komputer dengan jalur 
komunikasi kecepatan tinggi, yang membawa data, suara, dan video. Definisi ini memperlihatkan bahwa dalam teknologi informasi pada dasarnya terdapat dua komponen utama yaitu teknologi komputer dan teknologi komunikasi. Teknologi komputer yaitu teknologi yang berhubungan dengan komputer termasuk peralatanperalatan yang berhubungan dengan komputer. Sedang teknologi komunikasi yaitu teknologi yang berhubungan perangkat komunikasi jarak jauh, seperti telepon, feximil, dan televisi.

Definisi teknologi informasi yang lain dikemukakan Nina W. Syam (2004). Menurutnya teknologi informasi dapat dimaknai sebagai ilmu yang diperlukan untuk memanag informasi agar informasi tersebut dapat ditelusuri kembali dengan mudah dan akurat. Isi ilmu tersebut dapat berupa prosedur dan teknik-teknik untuk menyimpan dan mengelola informasi secara efisien dan efektif. Lebih lanjut menurut Nina W. Syam, informasi dipandang sebagai data yang telah diolah dan dapat disimpan baik dalam bentuk tulisan, suara, maupun dalam bentuk gambar, dimana gambar tersebut dapat berupa gambar mati atau gambar hidup. Sedang informasi yang dikelola atau disampaikan melalui teknologi informasi tersebut dapat berupa ilmu dan pengetahuan itu sendiri. Bila informasi tersebut volumenya kecil tentu tidak memerlukan teknik-teknik atau prosedur yang rumit untuk menyimpannya. Namun bila informasi tersebut dalam volume yang cukup besar, maka diperlukan teknik atau prosedur tertentu untuk menyimpannya, agar mudah menemukan kembali informasi yang tersimpan. Teknik atau prosedur untuk mengelola informasi itulah yang disebut dengan teknologi informasi.

Berdasarkan dua definisi di atas, dapat disimpulkan bahwa teknologi informasi secara sederhana dapat dipandang sebagai ilmu yang diperlukan untuk mengelola/memanag informasi agar informasi tersebut dapat secara mudah dicari atau ditemukan kembali. Sementara dalam pelaksanaannya untuk dapat mengelola informasi tersebut dengan baik, cepat, dan efektif, maka diperlukan teknologi komputer sebagai pengolah informasi dan teknologi komunikasi sebagai penyampai informasi jarak jauh.

\section{B. Pemanfaatan Teknologi Informasi Untuk Meningkatkan Kualitas Dan Efektifitas Pendidikan}


Perkembangan teknologi informasi (TI) yang sangat pesat merupakan potensi untuk meningkatkan kualitas pendidikan. Internet sebagai anak kandung dari teknologi informasi menyimpan informasi tentang segala hal yang tidak terbatas, yang dapat digali untuk kepentingan pengembangan pendidikan. Dengan internet belajar tidak lagi dibatasi ruang dan waktu. Keberadaan teknologi informasi bagi dunia pendidikan berarti tersedianya saluran atau sarana yang dapat dipakai untuk menyiarkan program pembelajaran baik secara searah maupun secara interaktif. Pemanfaatan teknologi informasi ini penting mengingat kondisi geografis Indonesia secara umum berada pada daerah pegunungan yang terpencar ke dalam banyak pulau-pulau. Dengan adanya teknologi informasi memungkinkan diselenggarakannya pendidikan jarak jauh, sehingga memungkinkan terjadinya pemerataan pendidikan di seluruh wilayah bumi Indonesia, baik yang sudah dapat dijangkau transportasi darat maupun yang belum dapat dijangkau dengan transportasi darat. Dengan demikian pemanfaatan teknologi informasi dalam pendidikan mempunyai arti penting terutama dalam rangka pemerataan pendidikan dan peningkatan kualitas serta efektifitas penyelenggaraan pendidikan di Indonesia.

Guna memanfaatkan teknologi informasi dalam proses pendidikan, terdapat beberapa langkah pengembangan yang dapat dilakukan antara lain sebagai berikut:

(1) Merancang dan membuat aplikasi database, yang menyimpan dan mengolah data dan informasi akademik, baik sistem perkuliahan, sistem penilaian, informasi kurikulum, manajemen pendidikan, maupun materi pembelajaran;

(2) Merancang dan membuat aplikasi pembelajaran berbasis portal, web, multimedia interaktif, yang terdiri atas aplikasi tutorial dan learning tool;

(3) Mengoptimalkan pemanfaatan TV edukasi sebagai materi pengayaan dalam rangka menunjang peningkatan mutu pendidikan; dan

(4) Mengimplementasikan sistem secara bertahap mulai dari lingkup yang lebih kecil hingga meluas, sehingga memudahkan managemen pemanfaatan TI dalam proses penyelenggaraan pendidikan.

Sedang pemanfaatan teknologi informasi dalam proses pendidikan secara garis besar meliputi:

\section{E-learning}


Menurut Onno W. Purbo (2002), E-learning merupakan bentuk teknologi informasi yang diterapkan di bidang pendidikan dalam bentuk maya. Melalui e-learning belajar tidak lagi dibatasi oleh ruang dan waktu. Belajar dapat dilakukan dimana saja dan kapan saja. Belajar mandiri berbasis kreativitas peserta didik yang dilakukan melalui e-learning mendorong peserta didik untuk melakukan analisa dan sintesa pengetahuan, menggali, mengolah, dan memanfaatkan informasi, menghasilkan tulisan, informasi dan pengetahuan sendiri. Peserta didik dirasang untuk melakukan eksplorasi ilmu pengetahuan.

E-learning dilakukan melalui jaringan internet, sehingga sumber belajar bukan hanya dosen, tetapi juga siapa saja yang ada diberbagai belahan dunia. Fasilitas yang dapat dimanfaatkan oleh peserta didik untuk belajar melalui elearning diantaranya: e-book, elibrary, interaksi dengan pakar, email, mailing list, news group, worl wide web (www), dan lain-lain. Situs-situs yang menyediakan e-learning beberapa diantaranya yaitu: pendidikan.net, educasi.net, ilmu komputer, fisika.net, fisikamu.net untuk fisika, cascadeimei untuk matematika, plasa.com, pintar media.com dan banyak lagi situs lainnya.

Pelaksanaan e-learning dapat dilakukan oleh berbagai pihak. Perdosenan tinggi dan sekolah diharapkan mampu untuk menyelenggarakan e-learning sendiri. Secara sederhana elearning dapat dilaksanakan oleh dosen dengan membuat situs sendiri atau situs sekolah yang di-link dengan situs-situs yang berkaitan dengan pelajarannya. Situs dosen'sekolah dapat diisi dengan materi pelajaran yang dapat divisualisasikan, tugas-tugas dan evaluasi.

2. Media Pembelajaran

Pemanfaatan teknologi informasi sebagai media pembelajaran dapat melalui pemanfaatan internet dalam e-learning maupun penggunaan komputer sebagai media interaktif. Diharapkan dengan penggunaan media ini dapat merangsang pikiran, perasaan, minat serta perhatian peserta didik sedemikian rupa sehingga proses pembelajaran dapat terjadi. Selaian itu, proses pembelajaran akan lebih efektif karena penggunaan media pembelajaran memungkinkan teratasinya hambatan dalam proses komunikasi dosen-peserta didik seperti hambatan fisiologis, psikologis, kultural, dan lingkungan.

Para peneliti menemukan bahwa ada berbagai cara peserta didik dalam memproses informasi belajar yang bersifat unik. Sebagian siswa lebih mudah memproses informasi belajar secara visual, sebagian lain lebih mudah memproses informasi melalui suara 
(auditorial), dan sebagian lain lebih mudah memproses informasi belajar dengan cara melakukan sentuhan/praktek langsung atau kinestetik (Bobby DePorter \& Mike Hernacki, 1999). Efektifitas belajar sangat dipengaruhi gaya belajar dan bagaimana cara belajar. Menurut Bobby DePorter (1999), 10\% informasi diserap dari apa yang kita baca, 20\% dari apa yang kita dengar, 30\% dari apa yang kita lihat, 50\% dari apa yang kita lihat dan dengar, $70 \%$ dari apa yang kita katakan, dan 90\% dari apa yang kita katakana dan kita lakukan. Sesuai dengan hasil penelitian DePorter tersebut, computer memenuhi persyaratan sebagai media pembelajaran yang efektif, karena komputer mampu menyuguhkan informasi yang berupa video, audio, teks, grafik, dan animasi, serta penggunaannya melibatkan ketrampilan kinestetik.

Secara umum pemanfaatan teknologi informasi sebagai media pembelajaran dapat dikategorikan menjadi tiga kelompok. Pemanfaatan kelompok pertama, memanfaatkan komputer sebagai media penyampaian materi ajar, yang biasa dikenal dengan istilah Computer Assisted Instruksional (CAI) atau Computer-Based Training (CBT). Pada pemanfaatan jenis ini, informasi (materi belajar) yang hendak disampaikan kepada peserta didik dikemas dalam suatu perangkat lunak (program). Peserta didik kemudian dapat belajar dengan cara menjalankan program atau perangkat lunak tersebut di komputer. Bila dirancang dengan baik, dapat diciptakan paket program pembelajaran untuk melakukan simulasi atau materi praktek, yang juga dapat memberikan umpan balik secara langsung terhadap kemajuan belajar peserta didik tersebut melalui rekaman hasil evaluasi belajar.

Pemanfaatan kelompok kedua memanfaatkan teknologi informasi sebagai media pendistribusian materi ajar melalui jaringan internet. Materi ajar dapat dikemas dalam bentuk webpage, atau pun program belajar interaktif (CAI atau CBI). Materi ajar ini kemudian ditempatkan di sebuah server yang tersambung ke internet, sehingga dapat diambil oleh peserta didik baik dengan menggunakan web broser atau file transport protocol (aplikasi pengiriman file).

Pemanfaatan kelompok ketiga memanfaatkan teknologi informasi sebagai media komunikasi dengan pakar, atau nara sumber, atau peserta didik yang lainnya (teleconferences). Momen komunikasi ini dapat digunakan untuk menanyakan hal-hal yang tidak bisa dimengerti, atau mengemukakan pendapat supaya dapat ditanggapi oleh peserta 
didik yang lain atau oleh dosen. Dengan demikian, peserta didik bisa mendapat umpan balik dari pakar atau dari nara sumber serta dari teman peserta didik yang lain mengenai hal-hal yang berkaitan dengan pemahaman materi ajar.

\section{Pendidikan Life Skill}

Teknologi informasi dengan komputer sebagai jantungnya telah memasuki berbagai aspek kehidupan. Hampir semua bidang pekerjaan membutuhkan komputer. Pekerjaan yang membutuhkan ketrampilan menggunakan komputer terbuka luas. Ketrampilan menggunakan computer merupakan salah satu kecakapan hidup yang sangat dibutuhkan untuk bersaing dalam sistem ekonomi berbasis ilmu pengetahuan.

Pendidikan teknologi informasi mengandung kecakapan hidup yang dapat dikembangkan baik specific life skill maupun general life skill. Kecakapan dalam mengoperasikan komputer menggunakan program, baik aplikasi maupun bahasa pemrograman merupakan kecakapan hidup yang bersifat vokasional. Sementara ketrampilan menggali informasi internet pada internet, mengolah dan memanfaatkannya merupakan general life skill.

\section{METODE PENELITIAN}

Penelitian ini merupakan penelitian studi kasus dengan mengambil lokasi pengamatan di Kampus Universitas Islam Negeri Alauddin Makassar dan Universitas Al-Asyariah Mandar. Data penelitian dikumpulkan berdasarkan data kehadiran mahasiswa yang mengikuti perkuliahan selama periode pembelajaran jarak jauh berbasis daring atau online. Adapun jumlah mahasiswa yang dijadikan sampel penelitian sebanyak 52 orang yang terdiri dari 34 orang dari Universitas Islam Negeri Alauddin Makassar dan 18 orang dari Universitas Al-Asyariah Mandar. Data yang diperoleh selanjutnya dianalisis menggunakan metode statistik deskriptif untuk memudahkan dalam mengidentifikasi variable penelitian, yang dalam hal ini adalah keterbatasan kuota internet dan perangkat yang tidak kompetibel.

\section{HASIL DAN PEMBAHASAN}

Sebagaimana yang dijelaskan pada tinjauan pustaka bahwa teknologi informasi sangat erat kaitannya dengan ketersediaan internet yang memadai dan kemampuan perangkat dalam 
menyesuaikan aplikasi e-learning. Hal ini sangat berpengaruh terhadap kondisi finansial peserta didik maupun dosen itu sendiri. Adapun beberapa aplikasi e-learning yang digunakan saat perkuliahan antara lain Zoom, Google Meet, dan Google Classroom. Peserta didik dapat memilih lebih dari satu aplikasi, mengingat proses perkuliahan menggunakan lebih dari satu aplikasi karena belum ada aplikasi yang kompleks yang menyediakan fitur e-learning yang lengkap. Dari hasil rekapitulasi data diketahui aplikasi Google Classroom menjadi aplikasi dominan yang digunakan sebagai media e-learning yang disusul aplikasi Zoom kemudian Google Meet. (lihat gambar 1)

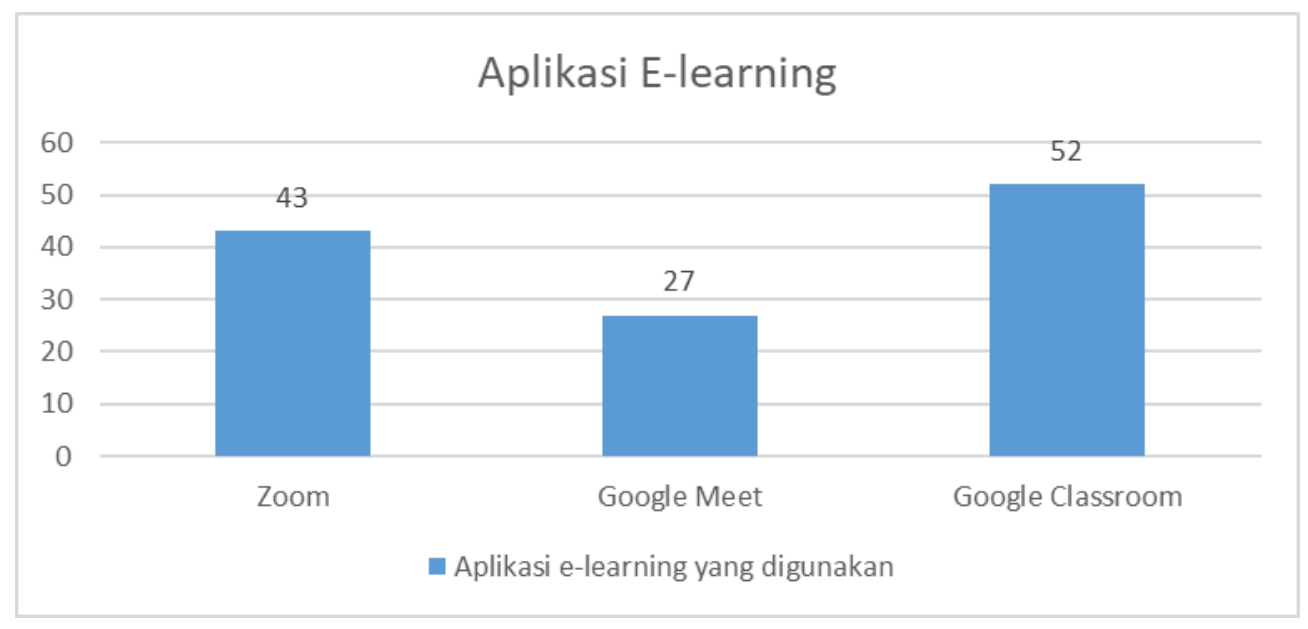

Gambar 1. Total pengguna aplikasi e-learning

Sejak diberlakukannya perkuliahan daring ini, juga berdampak pada tingkat kehadiran mahasiswa maupun keikutsertaan mahasiswa yang cenderung terlambat karena kendala jaringan atau ketersediaan kouta internet yang kurang memadai. Hal ini dapat dilihat pada grafik berikut (lihat gambar 2), dimana memasuki perkuliahan minggu ke 9 tingkat kehadiran mahasiswa mengalami penurunan hingga $31 \%$. 


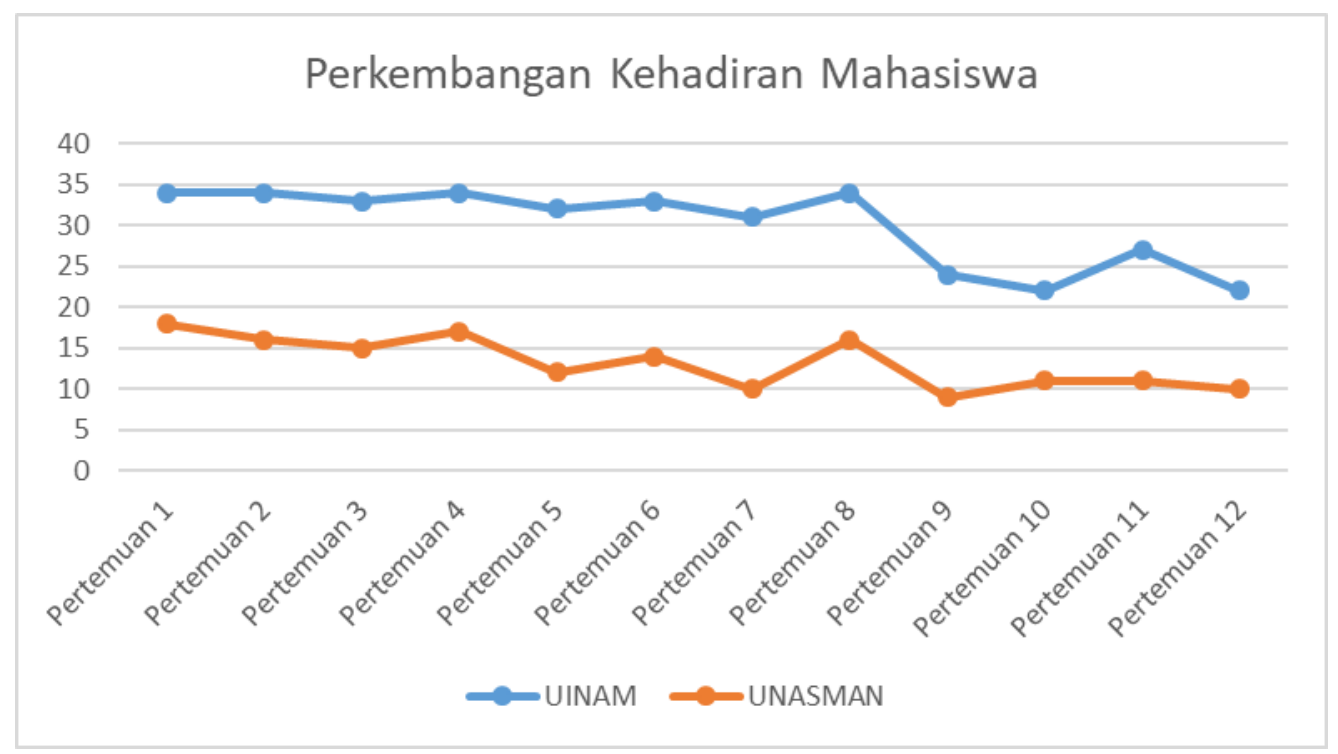

Gambar 2. Perkembangan tingkat kehadiran mahasiswa selama perkuliahan daring

Dari hasil analisis yang dilakukan diketahui bahwa 37 dari 52 mahasiwa mengalami kendala keterbatasan kuota dalam mengikuti proses perkuliahan yang dilakukan menggunakan video conference karena besarnya beban kuota yang dibutuhkan saat perkuliahan berlangsung. Berdasarkan informasi dari sampel penelitian, diketahui durasi perkuliahan antara 100 - 150 menit membutuhkan kurang lebih 500 - 700 mb menggunakan aplikasi Zoom sedangkan 150 - 280 mb menggunakan Google Meet. Namun, banyak dosen yang cenderung menggunakan aplikasi Zoom dalam proses perkuliahan sehingga memberatkan mahasiswa untuk ikut dalam perkuliahan tersebut. Sehingga tidak jarang dari setiap pertemuan perkuliahan daring jumlah mahasiswa yang ikut dalam perkuliahan semakin berkurang hingga berkisar $31 \%$ dari jumlah total keseluruhan peserta kuliah.

Sedangkan penggunaan aplikasi Google Classroom juga tidak luput dari permasalahan ketika pengumpulan tugas dengan kapasitas file yang cukup besar ataupun ketika pengunduh link materi video maupun materi berupa modul perkuliahan. Segala permasalahan yang dialami mahasiswa tidak terlepas dari keterbatasan kuota yang dimiliki kerena ketidakmampuan dalam memenuhi kebutuhan kuota yang maksimal. Disamping itu, 
beberapa perangkat IT yang juga tidak mampu mengimbangi media pembelajaran daring. Sehingga mereka harus menyediakan perangkat yang kompatibel dengan media pembelajaran atau system e-learning yang digunakan pada perkuliahan. Segala permasalahan tersebut dapat teratasi jika kemampuan finansial mereka memadai. Adapun biaya yang dibutuhkan oleh mahasiswa dalam memenuhi kebutuhan internet setiap bulan mencapai Rp. 400.000,- yang dirasakan cukup berat bagi sebagian besar mahasiswa. Disamping itu, kondisi finansial keluarga mereka juga terbatas. Oleh karenanya, dampak pembelajaran daring ini tidak hanya dirasakan oleh mahasiswa itu sendiri tetapi juga dirasakan orang tua mereka.

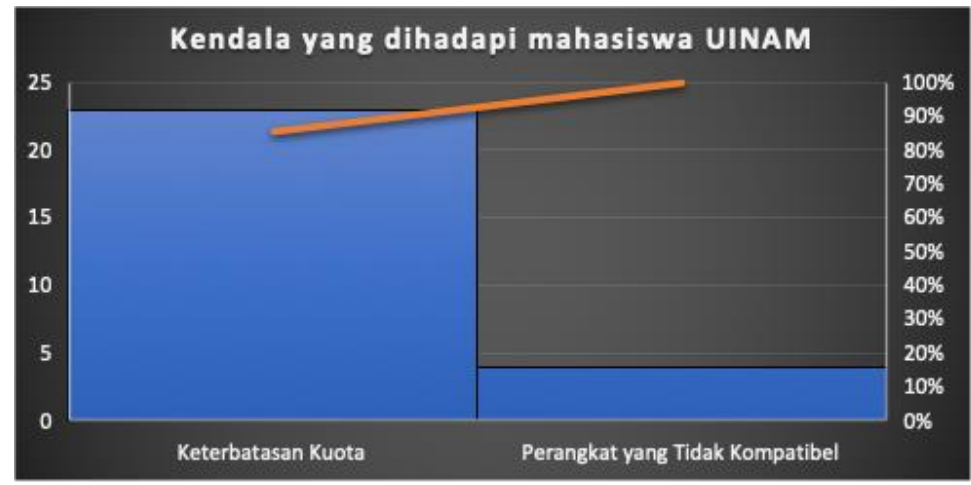

Gambar 3. Kendala yang dialami mahasiswa selama perkuliahan daring (1) 


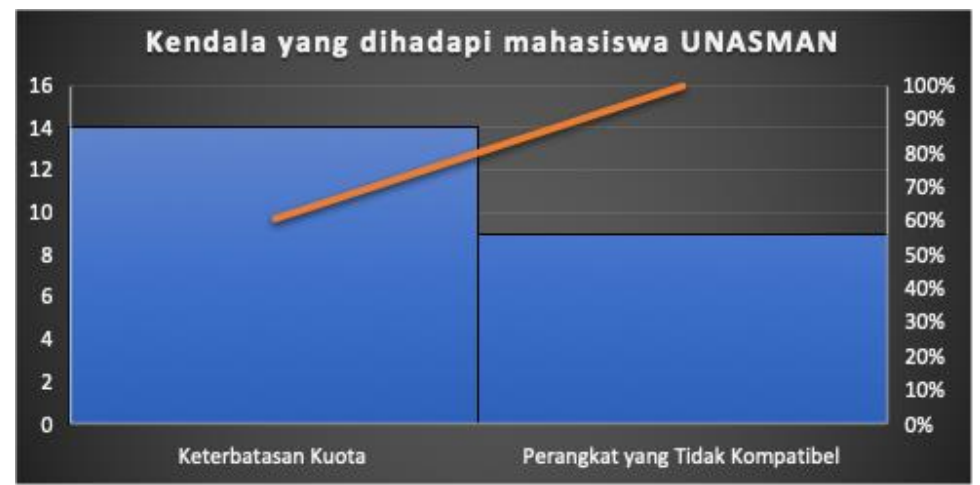

Gambar 4. Kendala yang dialami mahasiswa selama perkuliahan daring (2)

Permasalahan finansial ini berdampak pada beberapa hal seperti :

1.Sekitar $29 \%$ dari 52 perseta didik tersebut harus mundur perkuliahan daring karena tidak mampu menyediakan kuota lebih untuk mengikuti perkuliahan daring (tingkat kehadiran tidak memenuhi ketentuan yang berlaku)

2.Sekitar $25 \%$ peserta didik tidak memiliki perangkat yang kompatibel dengan media pembelajaran daring atau system e-learning, sehingga mereka harus menyediakan perangkat kompatibel yang membutuhkan biaya yang sangat besar untuk penggantian ataupun mengadaan perangkat IT tersebut

Dalam proses Pembelajaran Jarak Jauh saat ini, memaksa dunia pendidikan beradaptasi dengan teknologi komunikasi serta berbagai platform digital untuk mendukung proses pembelajaran. Pembelajaran Jarak Jauh dengan segala dinamikanya masih merupakan pilihan yang logis agar para mahasiswa tetap belajar dan menghindari penyebaran virus Corona. Namun, banyak hal yang perlu dipersiapkan bagi dari pemerintah maupun pihak institusi untuk mengatasi permasalahan yang dialami oleh mahasiswa karena sangat berdampak pada prestasi akademik mahasiswa tersebut. 


\section{PENUTUP}

\section{Kesimpulan}

Pembelajaran daring atau perkuliahan daring pada dasarnya bukan hal baru didunia Pendidikan tetapi belum sepenuhnya disosialisasikan untuk diterapkan diseluruh sektor pendidikan formal. Hal ini menjadi tantangan tersendiri bagi pelaku perkuliahan seperti mahasiswa, dimana keterbatasan finansial sangat berpengaruh terhadap keikutsertaan dan keaktifan mereka dalam proses perkuliahan daring. Oleh karena itu, perkuliahan daring ini membutuhkan perhatian dari berbagai pihak khususnya dalam pemilihan aplikasi e-learning yang efektif dan efisien agar dampak teknologi informasi dalam perkuliahan daring dapat diminimalisir atau direduksi.

\section{DAFTAR PUSTAKA}

Abdul Kadir \& Terra CH. (2003). Pengenalan Teknologi Informasi. Yogyakarta: Andi Offset.

Abrianto, D., \& Sitompul, H. (2014). Penggunaan Media Pembelajaran Berbasis Komputer Dan Sikap Inovatif Terhadap Hasil Belajar Teknologi Informasi Dan Komunikasi. Jurnal Teknologi Informasi \& Komunikasi Dalam Pendidikan, 1(1), 50-62.

Anonim. (2020). Dinamika Pembelajaran Jarak Jauh di Era Pandemi COVID-19. Puspensos. Diakses desember 2020 https://puspensos.kemsos.go.id/dinamika-pembelajaran-jarakjauh-di-era-pandemi-covid-19

B. Uno, H. . (2010). Teknologi Komunikasi dan Informasi Pembelajaran. Jakarta: Bumi Aksara.

Baharudin, R. (2010). Keefektifan Media Belajar Berbasis Teknologi Informasi Dan Komunikasi. Tadrîs, 5(1), 112-127.

Bobby DePorter (1999). Quantum Learning. Jakarta: Kaifa

Budiman, M. A. (2012). Pemanfaatan Teknologi Informasi dan Komunikasi dalam Kelas Bahasa Inggris. Semantik, 2(1), 9-14.

Budiman, Yusrizal, \& Damanik, J. (2014). Akses Dan Penggunaan Teknologi Informasi Dan Komunikasi Pada Rumah Tangga Dan Individu. Jurnal Penelitian Komunikasi Dan Pembangunan, 15(1), 1-16.

Diat, Prasojo, L. (2011). Teknologi Informasi Pendidikan. Yogyakarta: Gaya Media.

Geger Riyanto (2006). Teknologi Informasi dan Pendidikan di Indonesia. Diambil pada tanggal 30 Agustus 2020, dari http://www.e-dukasi.net /artikel.php?id=30.com/

Hildayanti, A., \& Machrizzandi, M. S. R. (2020). Sistem Rekayasa Internet Pada Implementasi Rumah Pintar Berbasis IoT. Jurnal Ilmiah Ilmu Komputer Fakultas Ilmu Komputer Universitas Al Asyariah Mandar, 6(1), 45-51. 
Hildayanti, A., \& Machrizzandi, M. S. R. (2020). THE APPLICATION OF IOT (INTERNET OF THINGS) FOR SMART HOUSING ENVIRONMENTS AND INTEGRATED ECOSYSTEMS. Nature: National Academic Journal of Architecture, 7(1), 80-88.

Nina W. Syam (2004). Teknologi Informasi dan Komunikasi dalam Dunia Pendidikan. Makalah disampaikan dalam diskusi panel tentang Teknologi Informasi pada hari Sabtu, 18 Desember 2004, di Universitas Pendidikan Indonesia Bandung.

Onno W. Purbo (2002). Teknologi e-Learning. Jakarta: Elex Media Komputindo 